\title{
Leptin expression in offspring is programmed by nutrition in pregnancy
}

\author{
J E Ekert ${ }^{1}$, K L Gatford ${ }^{2}$, B G Luxford ${ }^{3}$, R G Campbell ${ }^{4}$ and P C Owens ${ }^{1}$ \\ ${ }^{1}$ Department of Obstetrics and Gynaecology, University of Adelaide, Adelaide 5005, Australia \\ 2Department of Physiology, University of Adelaide, Adelaide 5005, Australia \\ ${ }^{3}$ Research and Development Unit, Bunge Meat Industries Ltd, Corowa 2646, Australia \\ ${ }^{4}$ United Feeds, PO Box 108, Sheridan, Indiana 46069, USA \\ (Requests for offprints should be addressed to P C Owens)
}

\begin{abstract}
Birth weight is a determinant of blood leptin concentrations in adults. Since nutrition during pregnancy can affect birth weight, the hypothesis that feed intake during pregnancy alters leptin expression in progeny was examined. Leptin mRNA was measured in subcutaneous adipose tissue and leptin protein was measured in blood plasma from 59 day old female pigs whose mothers were fed at the same restricted rate except
\end{abstract}

that half were permitted to consume $35 \%$ more feed during the second quarter of pregnancy. Leptin mRNA abundance in adipose tissue $(P=0.015)$ and plasma leptin concentration $(P=0.01)$ were higher in progeny from mothers provided with more feed. Body weight at birth was negatively correlated with the abundance of leptin mRNA in subcutaneous fat at 59 days of age $(P=0.01)$. This study shows for the first time that maternal nutrition during pregnancy programs postnatal leptin expression in offspring.

Journal of Endocrinology (2000) 165, R1-R6

\section{Introduction}

Leptin is a polypeptide hormone synthesised and secreted into systemic blood principally by adipocytes that acts at the hypothalamus to suppress ingestive behaviour and increase energy expenditure (Friedman \& Halaas 1998, Houseknecht $e t$ al. 1998, Mantzoros \& Moschos 1998, Barb 1999, Ramsay 1999). In adults, abundance of leptin mRNA in adipose tissue and concentrations of leptin protein in blood correlate positively with concurrent body weight and adiposity (Maffei et al. 1995, Considine et al. 1996). Leptin appears to be involved in the relationship between biomass and energy reserve from early in life because there are positive associations between the concentrations of leptin protein in human umbilical cord blood and both body weight and adiposity at birth (Schubring et al. 1997, Koistinen et al. 1997, Jaquet et al. 1999, Ong et al. 1999). Furthermore, leptin mRNA abundance in fetal adipose tissue is positively correlated with fetal body weight in sheep (Yuen et al. 1999). Blood leptin levels in adults are also influenced by factors acting at or before birth. Independent studies of 502 men and women born in England in the 1920s (Phillips et al. 1999) and 1462 women born in Sweden between 1908 and 1930 (Lissner et al. 1999) concluded that body weight at birth is related to blood leptin concentrations in adults, independent of adult adiposity. However, unlike the positive correlations seen in fetuses, newborns and adults between concurrent measures of leptin production and body weight or adiposity, the correlation between body weight at birth and leptin protein concentration in blood from adults is negative. Maternal nutrition during pregnancy affects body weight of the fetus (Lemons et al. 1986, Harding \& Johnston 1995, Sohlström et al. 1998), newborn (Corah et al. 1975, Lechtig et al. 1975, Godfrey et al. 1996, Wallace et al. 1997) and adult (Barker 1997). The effect of nutrition during pregnancy on postnatal leptin expression in offspring was therefore examined.

\section{Materials and Methods}

Animals

The study was designed in accordance with the Australian code of practice for the care and use of animals for scientific purposes (6th edn 1997, National Health \& Medical Research Council) and approved by the Animal Experimentation Ethics Committee of Bunge Meat Industries. Large White gilts (primiparous sows, $n=16$ ) were fed a dry ration containing 13.5 MJ digestible energy and $150 \mathrm{~g}$ protein per $\mathrm{kg}$ at $2.2 \mathrm{~kg} . \mathrm{d}^{-1}$. From the 25 th day of pregnancy $(140.8 \pm 2.4 \mathrm{~kg}$ live weight) to the 50th day, half were fed the same diet at 3.0 kg. $\mathrm{d}^{-1}$ (term $\sim 110$ days). A female piglet of median birth weight for her litter was killed by barbiturate overdose 59 days after birth. The study was confined to one sex to avoid the confounding effects of gender on growth phenotype (Tanner 1962, Bereskin \& Steele 1986) and plasma leptin concentration (Mantzoros \& Moschos 1998). Hindquarter 
subcutaneous fat was frozen in liquid $\mathrm{N}_{2}$ and stored at $-80^{\circ} \mathrm{C}$. Jugular venous EDTA-plasma was stored at $-20^{\circ} \mathrm{C}$.

\section{Adipose tissue content}

DNA content was measured after $1.03 \pm 0.02 \mathrm{~g}$ of thinly sliced adipose tissue was homogenised and sonicated in $10 \mathrm{ml}$ chloroform:methanol $(2: 1, \mathrm{vol} / \mathrm{vol})$ and delipidated by repeated inversion at 30 r.p.m. for $15 \mathrm{~h}$ at $25^{\circ} \mathrm{C}$ (Colebrook et al. 1988). Cell fragments were recovered from the interphase after centrifugation at $2500 \mathrm{~g}$ for $10 \mathrm{~min}$ at $4^{\circ} \mathrm{C}$ and their DNA content measured by a modification (Gendimenico et al. 1988) of the diphenylamine method (Burton 1956). RNA concentration was determined from absorbance at $260 \mathrm{~nm}$ of RNA hydrolysates (Van den Hoff et al. 1997) prepared from delipidated homogenates of $207 \pm 8 \mathrm{mg}$ of adipose tissue in $3 \mathrm{ml}$ of $10 \mathrm{mmol} / \mathrm{l}$ sodium phosphate $\mathrm{pH}$. Tissue protein was measured using the BCA (bicinchoninic acid) Protein Assay Reagent according to the manufacturer's instructions (23225X, Pierce Chemical Co, Rockford, IL, USA). Dry matter content was measured after dehydration at $140^{\circ} \mathrm{C}$ for $24 \mathrm{~h}$. Lipid content was assumed to be the dry residue after subtraction of DNA, RNA and protein content.

\section{Reverse transcription polymerase chain reactions}

RNA was extracted with TRIzol (GibcoBRL, Gaithersburg, MD, USA) from one adipose specimen $(196 \pm 9 \mathrm{mg})$ from each animal at a yield of $0.63 \pm 0.03 \mathrm{mg} / \mathrm{g}$. cDNA was obtained by reverse transcription of $1 \mu \mathrm{g}$ total RNA with random sequence hexanucleotides (RP-6, GeneWorks, Adelaide, Australia) and SuperScript RNase $\mathrm{H}^{-}$(18053-017, GibcoBRL). A porcine leptin cDNA fragment was amplified with Taq* DNA polymerase (Biotech International, Bently, Australia) through 30 cycles of $15 \mathrm{~s}$ at $94^{\circ} \mathrm{C}, 15 \mathrm{~s}$ at $53^{\circ} \mathrm{C}$ and $15 \mathrm{~s}$ at $72^{\circ} \mathrm{C}$ (Hybaid PCR Express, Teddington, UK) with $5^{\prime}$-TTC CTG TGG CTT TGG CCC-3' and 5'-AGC TCT TGG AGG AGG CCA GC-3' (GeneWorks) as primers. This produced $326 \mathrm{bp}$ of ds cDNA. Sequencing by the ABI PRISM Dye Terminator method (Perkin-Elmer, Foster City, California) after QIAquick purification (Qiagen Pty. Ltd, Clifton Hill, Australia) confirmed its identity as nucleotides 24-349 of the 504 nucleotide porcine leptin cDNA (Genbank Acc. No. U59894). A 349 bp fragment of porcine $\beta$-actin cDNA was similarly amplified with 5'-TGT GAT GGT GGG TAT ATG GGT C-3' and 5'-TAG ATG GGC ACA GTG TGG GT-3' (GeneWorks) as primers and its identity confirmed as above (GenBank Acc. No. V01217 J00691). Leptin and $\beta$-actin cDNA fragments amplified as above with digoxigenin-dUTP included in the PCR (Cat. 1636120, Roche Diagnostics, Mannheim, Germany) were measured by digoxigenin PCR ELISA (Cat. 1636111, Roche) after immobilisation to streptavidin-coated microtitre plates using 5'-biotinylated oligonucleotides complementary to either porcine leptin cDNA (5'-TCC TCA CCA GTC TGC CC-3') or porcine $\beta$-actin cDNA (5'- CAA GAG AGG CAT CCT GAC CC -3'). Assays were calibrated with digoxigenin- labelled leptin or $\beta$-actin cDNA fragments for which the concentration of leptin or $\beta$-actin ds cDNA was previously determined by comparing their ethidium bromide staining intensities with those of DNA standards of known mass (DMW-P1, GeneWorks) after agarose gel electrophoresis.

\section{Plasma leptin radioimmunoassay}

Leptin protein was measured in plasma by RIA using human [125I]-leptin (cat. 9081), guinea pig antiserum (cat. XL-85K) to human leptin (both from Linco Research, St Charles, MO, USA) and human leptin (R\&D Systems, Minneapolis, MN, USA) as standard. Dose-responses for pig plasma and human leptin were parallel. Leptin was measured in all plasma

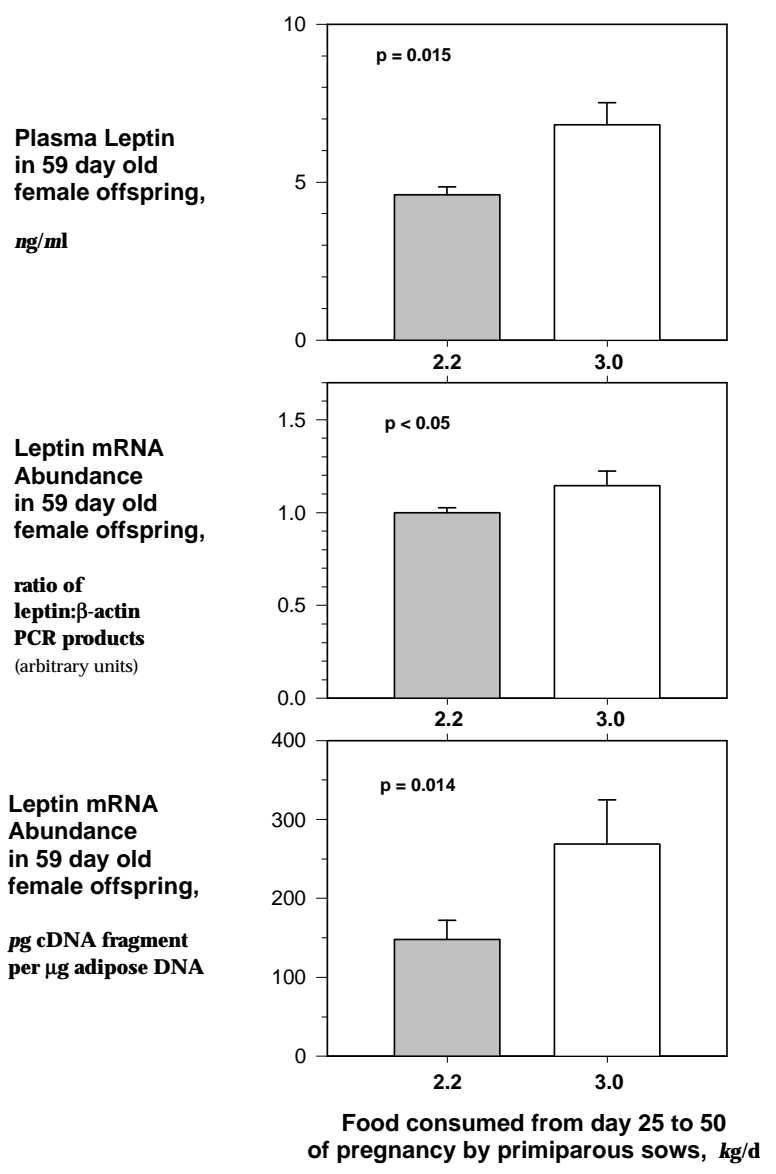

Figure 1 Maternal nutrition in the second quarter of pregnancy and measures of leptin production in 59 day old offspring. 


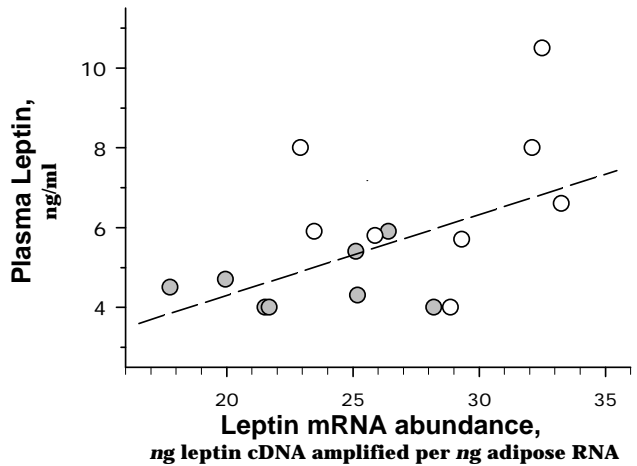

Figure 2 Relationship between leptin mRNA abundance in adipose tissue and leptin protein concentration in plasma 59 days after birth in offspring of mothers fed either 2.2 (shaded circle) or 3.0 (open circle) $\mathrm{kg} / \mathrm{d}$ during the second quarter of pregnancy $(r=0.54, P=0.03)$.

samples in a single assay (intra-assay $\mathrm{CV}=4 \%$ ) and is expressed in human leptin equivalents.

\section{Statistics}

Results are presented as mean \pm S.E.M. Effects of nutrition were assessed by $t$-test. Associations were evaluated by linear regression (SigmaStat V1, Jandel, San Rafael, CA, USA).

\section{Results}

Maternal nutrition during the second quarter of pregnancy had no significant effect on the number of animals born alive per pregnancy $(10.8 \pm 0.4)$, the number of stillbirths per pregnancy $(0.63 \pm 0.27)$ or body weight at birth $(1.43 \pm 0.05 \mathrm{~kg})$. Feed during pregnancy did not affect body weight at birth or at 59 days of age $(20.8 \pm 1.2 \mathrm{~kg})$ for median birthweight females selected from each litter.

Neither the content of lipid $(500 \pm 24 \mathrm{mg} / \mathrm{g})$, water (478 \pm $2 \mathrm{mg} / \mathrm{g}$ ), protein $(21.1 \pm 2.3 \mathrm{mg} / \mathrm{g})$, RNA $(683 \pm 49 \mu \mathrm{g} / \mathrm{g}$ ) nor DNA $(97.5 \pm 8.5 \mu \mathrm{g} / \mathrm{g})$ in subcutaneous adipose tissue at 59 days of age in the selected offspring was affected by maternal nutrition during pregnancy. Mass ratios (g/g) of RNA:DNA $(8.2 \pm 1.4)$, protein:DNA $(280 \pm 80)$ and lipid:DNA (5600 \pm 402) were similarly unaffected.

Food availability during the second quarter of pregnancy altered both the concentrations of leptin protein in blood plasma and the abundance of leptin mRNA in subcutaneous adipose tissue of 59 day old progeny. Plasma leptin was $\sim 30 \%$ higher, the ratio of leptin/ $\beta$-actin mRNA in adipose tissue was $\sim 15 \%$ higher, abundance of leptin mRNA per $\mu$ g adipose DNA was $\sim 80 \%$ higher (Fig. 1) and the amount of leptin cDNA fragment amplified per ng adipose RNA was $~ 20 \%$ higher (28.4 \pm 1.4 versus $23.1 \pm 1.3, P=0.015)$ in offspring from mothers provided more food. Nutrition in pregnancy did not affect abundance of $\beta$-actin mRNA in adipose tissue of progeny $(P>0.2)$.

Leptin protein concentration in plasma was positively correlated with leptin mRNA abundance per ng adipose RNA (Fig. 2) and tended to correlate with leptin mRNA abundance per $\mu$ g adipose DNA ( $r=+0.45, P=0.09)$ but was not related to the ratio of leptin/ $\beta$-actin mRNA $(P>0.3)$.

Abundance of leptin mRNA per cell (i.e. pg leptin cDNA fragment amplified per $\mu \mathrm{g}$ adipose DNA) was positively correlated with all measures of adipose cell size (RNA/DNA $r=+0.96, \quad P<0.0001 ; \quad$ protein/DNA $\quad r=+0.88, \quad P<0.0001$; lipid/DNA $r=+0.64, P<0.01)$.

Body weight at birth was negatively correlated with leptin mRNA abundance per ng adipose RNA (Fig. 3) and with the ratio of leptin/ $\beta$-actin mRNA $(r=-0.51, P<0.05)$ at 59 days of age.

\section{Discussion}

In the present study weight of progeny at birth and at 59 days of age were unaffected by the amount of feed provided to mothers during the second quarter of pregnancy. Adipose cell size and subcutaneous adipose composition of DNA, RNA, protein and lipid were similarly unaffected.

Measures of leptin production in offspring were programmed by maternal nutrition. Greater food availability to pregnant mothers increased the concentration of leptin protein in blood and the abundance of leptin mRNA in adipose tissue. High abundance of leptin mRNA in adipose tissue and high

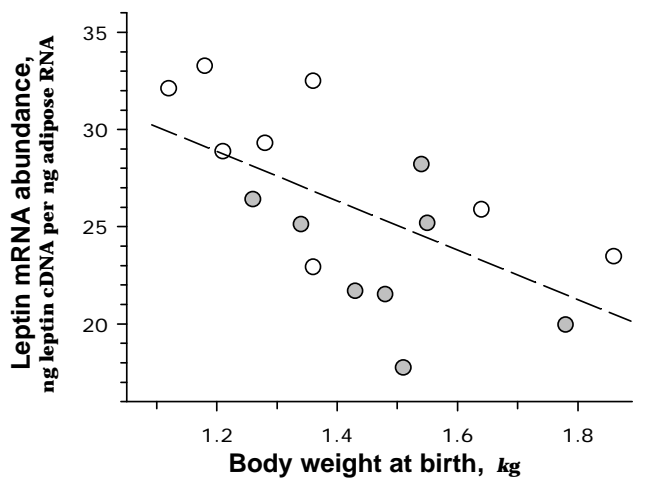

Figure 3 Relationship between weight at birth and leptin mRNA 59 days after birth from mothers fed either 2.2 (shaded circle) or 3.0 (open circle) $\mathrm{kg} / \mathrm{d}$ during the second quarter of pregnancy $(r=-0.62, P=0.01)$. 
plasma leptin concentrations are associated with greater adiposity in pigs (Robert et al. 1998, Spurlock et al. 1998, Owens et al. 1999) as in other mammals (Maffei et al. 1995, Considine et al. 1996, Lönnqvist et al. 1997). Maternal nutrition during pregnancy in rats can program obesity associated with larger adipocytes (Jones \& Friedman 1982, Shepherd et al. 1997). However, despite differences in leptin production there is no evidence of programmed obesity in the progeny analysed in the present study. Nutrition in pregnancy had no effect on body weight or adipose cell size. Differences in adiposity of the two groups of progeny might become evident at older ages, because leptin mRNA abundance in adipose tissue, plasma concentrations of leptin protein and body composition of fat increase with age in pigs (Spurlock $e t$ al. 1998, Barb et al. 1999, Owens et al. 1999).

The positive relationship observed in this study of adolescent female pigs between leptin mRNA abundance in adipose tissue and leptin protein concentration in blood is similar to that reported for adult women (Lönnqvist et al. 1997). In mice, rats and humans, adipocytes appear to be the major sites of leptin expression and secretion into blood (Frederich et al. 1995, Maffei et al. 1995). The results of this study indicate this is also the case in pigs.

The negative correlation between body weight at birth and subsequent expression of leptin in pigs is similar to recent observations in humans (Lissner et al. 1999, Phillips et al. 1999). The negative relationships in pigs and humans between body weight at birth and measures of leptin production in adolescents and adults are the opposite of the frequently reported positive correlations between concurrent measures of body weight or adiposity and leptin production seen in fetuses (Yuen et al. 1999), infants (Schubring et al. 1997, Koistinen et al. 1997, Jaquet et al. 1999, Ong et al. 1999) and adults (Considine et al. 1996, Lönnqvist et al. 1997). The negative relationship between birth weight and subsequent leptin production appears to be established in the first year of postnatal life in humans. While growth retarded newborn infants have lower than normal concentrations of leptin in their blood at birth, by 12 months of age they have higher than normal plasma leptin levels (Jaquet et al. 1999). This may be a consequence of 'catch-up' growth. Infants with lower plasma leptin concentrations at birth and lower body weights at birth tend to gain weight more rapidly in the first months of postnatal life (Ong et al. 1999, Jaquet et al. 1999). Lower birth weight infants may tend to have higher plasma leptin levels as juveniles and adults because 'catch-up' growth may increase their risk of obesity.

Permanent effects on progeny caused by environmental factors during pregnancy has been termed 'in utero programming' (Barker 1998). Blood pressure (Persson \& Jansson 1992, Woodall et al. 1996, Barker 1998), cholesterol metabolism (Lucas 1991, Barker 1998, Kind et al. 1999), insulin response to glucose (Lucas 1991, Barker 1998), glucose and lipid metabolism (Desai et al. 1995) and plasma concentrations of insulin-like growth factors (Muaku et al.
1996, Gallaher et al. 1998) in adults are all sensitive to influences acting before birth. Greater feed intake in the second quarter of pregnancy could theoretically increase postnatal expression of leptin by increasing the availability of glucose and/or other substrates to the fetus by a number of mechanisms (Lechtig et al. 1975, Lemons et al. 1986, Harding \& Johnson 1995, Gluckman et al. 1997) during a critical stage of adipocyte development. Whether substrates such as glucose can directly program leptin expression, possibly acting on preadipocytes in the fetus through UDP- $N$-acetylglucosamine (Wang et al. 1998) or other pathways (Fukada \& Iritani 1999), or whether this occurs indirectly through actions of fetal hormones such as insulin or insulin-like growth factor-I that are sensitive to nutrition (Gluckman et al. 1997) and are capable of regulating fetal adipocyte maturation (Hausman \& Hausman 1993, Martin et al. 1998) remains to be determined. Fetal tissues express leptin (Hoggard et al. 1997), including adipose tissue (Yuen et al. 1999), and leptin protein is detectable in fetal plasma from as early as 18 weeks gestation in humans (Jaquet et al. 1999). Regardless of the mechanism by which leptin is programmed in utero, the present study shows that maternal nutrition during pregnancy is a determinant of postnatal expression of leptin.

\section{Acknowledgements}

This work was supported by the Pig Research and Development Corporation of Australia. K L Gatford is a National Health and Medical Research Council (Australia) Peter Doherty Postdoctoral Fellow.

\section{References}

Barb CR 1999 The brain-pituitary-adipocyte axis: role of leptin in modulating neuroendocrine function. Journal of Animal Science 77 1249-1257.

Barb CR, Barrett JB, Kraeling RR \& Rampacek GB 1999 Role of leptin in modulating neuroendocrine function: a metabolic link between the brain-pituitary and adipose tissue. Reproduction in Domestic Animals 34 111-125.

Barker DJP 1998 In utero programming of chronic disease. Clinical Science 95 115-128.

Barker DJP, Gluckman PD, Godfrey KM, Harding JE, Owens JA \& Robinson JS 1993 Fetal nutrition and cardiovascular disease in adult life. Lancet 341 938-941.

Bereskin B \& Steele NC 1986 Performance of Duroc and Yorkshire boars and gilts in reciprocal breed crosses. Journal of Animal Science 62 918-926.

Burton K 1956 Determination of DNA concentration with diphenylamine. Biochemical Journal 62 315-323.

Colebrook WF, Black JL, Brown GH \& Donnelly JB 1988 Cellularity of organs in mature rams of different breeds. Australian Journal of Biological Science 41 201-214.

Corah LR, Dunn TG \& Kaltenbach CC 1975 Influence of prepartum nutrition on the reproductive performance of beef females and the performance of their progeny. Journal of Animal Science 41 819824. 
Considine RV, Sinha MK, Heiman ML, Kriauciunas A, Thomas W, Stephens TW, Nyce MR, Ohannesian JP, Marco CC, McKee LJ, Bauer TL \& Caro JF 1996 Serum immunoreactive leptin concentrations in normal-weight and obese humans. New England Journal of Medicine 334 292-295.

Desai M, Crowther NJ, Ozanne SE, Lucas A \& Hales N 1995 Adult glucose and lipid metabolism may be programmed during fetal life. Biochemical Society Transactions 23 331-335.

Frederich RC, Lollman B, Hamann A, Napolitano-Rosen A \& Kahn BB 1995 Expression of $o b$ mRNA and its encoded protein in rodents. Journal of Clinical Investigation 96 1658-1663.

Friedman JM \& Halaas JL 1998 Leptin and the regulation of body weight in mammals. Nature $\mathbf{3 9 5}$ 763-770.

Fukada H \& Iritani N 1999 Transcriptional regulation of leptin gene promoter in rat. FEBS Letters 455 165-169.

Gallaher BW, Brier BH, Keven CL, Harding JE \& Gluckman PD 1998 Fetal programming of insulin-like growth (IGF)-1 and IGFbinding protein-3: evidence of response to undernutrition in late gestation following exposure to periconceptual undernutrition in the sheep. Journal of Endocrinology 159 501-508.

Gendimenico GJ, Bouquin PL \& Tramposch KM 1988 Diphenylamine colorimetric method for DNA assay: a shortened procedure by incubating samples at $50^{\circ} \mathrm{C}$. Analytical Chemistry 173 45-48.

Gluckman PD, Robinson JS, Hales CN, Fowden A, Wollman HA \& Chatelain P 1997 Endocrine and nutritional regulation of prenatal growth. Acta Pediatrica, International Journal of Pediatrics (Suppl) 86 153-157.

Godfrey K, Robinson S, Barker DJP, Osmond C \& Cox V 1996 Maternal nutrition in early and late pregnancy in relation to placental and fetal growth. British Medical Journal 312 410-414.

Harding JE \& Johnston BM 1995 Nutrition and fetal growth. Reproduction, Fertility and Development 7 539-547.

Hausman GJ \& Hausman DB 1993 Endocrine regulation of porcine adipose tissue development: cellular and molecular aspects. In Growth of the Pig, pp 49-73. Ed GR Hollis. Wallingford, Oxon: CAB International.

Hoggard N, Hunter L, Duncan JS, Williams LM, Trayhurn P \& Mercer JG 1997 Leptin and leptin receptor mRNA and protein expression in the murine fetus and placenta. Proceedings of the National Academy of Sciences of the United States of America 94 1107311078.

Houseknecht KL, Baile CA, Matteri RL \& Spurlock ME 1998 The biology of leptin: a review. Journal of Animal Science 76 14051420.

Jaquet D, Leger J, Tabone MD, Czernichow P \& Levy-Marchal C 1999 High serum leptin concentrations during catch-up growth of children born with intrauterine growth retardation. Journal of Clinical Endocrinology and Metabolism 84 1949-1953.

Jones AP \& Friedman MI 1982 Obesity and adipocyte abnormalities in offspring of rats undernourished during pregnancy. Science $\mathbf{2 1 5}$ 1518-1519.

Kind KL, Clifton PM, Katsman AI, Tsiounis M, Robinson JS \& Owens JA 1999 Restricted fetal growth and the response to dietary cholesterol in the guinea pig. American Journal of Physiology 277 (Regulatory, Integrative and Comparative Physiology 46) R1675R1682.

Koistinen HA, Koivisto VA, Andersson S, Karonen S-L, Kontula K, Oksanen L \& Teramo KA 1997 Leptin concentration in cord blood correlates with intrauterine growth. Journal of Clinical Endocrinology and Metabolism 82 3328-3330.
Lechtig A, Habicht JP, Delgado H, Klein RE, Yarbrough C \& Martorell R 1975 Effect of food supplementation during pregnancy on birthweight. Pediatrics 56 508-520.

Lemons JA, Moorehead HC \& Hage GP 1986 Effects of fasting on gluconeogenic enzymes in the ovine fetus. Pediatric Research 20 676-679.

Lissner L, Karlsson C, Lindroos AK, Sjostrom L, Carlsson B, Carlsson L \& Bengtsson C 1999 Birth weight, adulthood BMI, and subsequent weight gain in relation to leptin levels in Swedish women. Obesity Research 7 150-154.

Lönnqvist F, Nordfors L, Jannson M, Thörne A, Schalling M \& Arner P 1997 Leptin secretion from adipose tissue in women: relationship to plasma levels and gene expression. Journal of Clinical Investigation 99 2398-2404.

Lucas A 1991 Programming by early nutrition in man, Wiley, Chichester.

Maffei M, Halaas J, Ravussin E, Pratley RE, Lee GH, Zhang Y, Fei H, Kim S, Lallone R, Ranganathan S, Kern PA \& Friedman JM 1995 Leptin levels in human and rodent- measurement of plasma leptin and $o b$ RNA in obese and weight-reduced subjects. Nature Medicine 1 1155-1161.

Mantzoros CS \& Moschos SJ 1998 Leptin: in search of role(s) in human physiology and pathophysiology. Clinical Endocrinology 49 551-557.

Martin RJ, Hausman GJ \& Hausman DB 1998 Regulation of adipose cell development in utero. Proceedings of the Society for Experimental Biology and Medicine 219 200-210.

Muaku SM, Beauloye V, Thissen JP, Underwood LE, Fossion C, Gerard G, Ketelslegers JM \& Maiter D 1996 Long-term effects of gestational protein malnutrition on postnatal growth, insulin-like growth factor (IGF)-I, and IGF-binding proteins in rat progeny. Pediatric Research 39 649-655.

Ong KKL, Ahmed ML, Sherriff A, Woods KA, Watts A, Golding J, the ALSPAC Study Team \& Dunger DB 1999 Cord blood leptin is associated with size at birth and predicts infancy weight gain in humans. Journal of Clinical Endocrinology and Metabolism 84 1145-1148.

Owens PC, Ekert JE \& Luxford BG 1999 Endogenous plasma leptin increases with age and is related to fatness and appetite. In Manipulating Pig Production VII, pp 176. Ed PD Cranwell. Werribee 3030, Australia: Australasian Pig Science Assn.

Persson E \& Jansson T 1992 Low birth weight is associated with elevated adult blood pressure in the chronically catheterised guinea pig. Acta Physiologica Scandinavia 145 195-196.

Phillips DIW, Fall CHD, Cooper C, Norman RJ, Robinson JS \& Owens PC 1999 Size at birth and plasma leptin concentrations in adult life. International Journal of Obesity 23 1025-1029.

Ramsay TG 1999 Leptin: a regulator of feed intake and physiology in swine. In Manipulating Pig Production VII, pp 157-170. Ed PD Cranwell. Werribee 3030, Australia: Australasian Pig Science Assn.

Robert C, Palin M-F, Coulombe N, Roberge C, Silversides FG, Benkel BF, McKay RM \& Pelletier G 1998 Backfat thickness in pigs is positively associated with leptin mRNA levels. Canadian Journal of Animal Science 78 473-482.

Schubring C, Kiess W, Englaro P, Rascher W, Dotsch J, Hanitsch S, Attanasio A \& Blum WF 1997 Levels of leptin in maternal serum, amniotic fluid, and arterial and venous cord blood: relation to neonatal and placental weight. Journal of Clinical Endocrinology and Metabolism 82 1480-1483. 
Shepherd PR, Crowther NJ, Desai M, Hales CN \& Ozanne SE 1997 Altered adipocyte properties in the offspring of protein malnourished rats. British Journal of Nutrition 78 121-129.

Sohlström A, Katsman A, Kind KL, Roberts CT, Owens PC, Robinson JS \& Owens JA 1998 Food restriction alters pregnancy-associated changes in IGF and IGFBP in the guinea pig. American Journal of Physiology 274 E410-E416.

Spurlock ME, Frank GR, Cornelius SG, Ji S, Willis GM \& Bidwell CA 1998 Obese gene expression in porcine adipose tissue is reduced by food deprivation but not by maintenance or submaintenance intake. Journal of Nutrition 128 677-682.

Tanner JM 1962 Growth at Adolescence, edn 2. Blackwell: Oxford

Van den Hoff MJB, Lekanne Deprez RH, Monteiro M, De Boer PAJ, Charles R \& Moorman AFM 1997 Developmental changes in rat cardiac DNA, RNA and protein tissue base: Implications for the interpretation of changes in gene expression. Journal of Molecular and Cellular Cardiology 29 629-639.

Wallace JM, Dasilva P, Aitken RP \& Cruickshank MA 1997 Maternal endocrine status in relation to pregnancy outcome in rapidly growing adolescent sheep. Journal of Endocrinology 155 359-368.

Wang J, Liu R, Hawkins M, Barzalai N \& Rossetti L 1998 A nutrientsensing pathway regulates leptin gene expression in muscle and fat. Nature 393 684-688.

Woodall SM, Johnston BM, Breier BH \& Gluckman PD 1996 Chronic maternal undernutrition in the rat leads to delayed postnatal growth and elevated blood pressure of offspring. Pediatric Research 40 438-443.

Yuen BSJ, McMillen IC, Symonds ME \& Owens PC 1999 Abundance of leptin mRNA in fetal adipose tissue is related to fetal body weight. Journal of Endocrinology 163 R11-R14. 